\title{
Classical Pluralism
}

\section{Introduction}

This chapter studies how military technology affected the geopolitical structure and economic performance of the greater Near East, Greece, Ganges India, China and Carthage. During this period, the defining military technological changes were the use of iron in warfare and, the rise of light cavalry and the combined arms legions, made up especially of light cavalry and light infantry.

While the pluralistic Greek, Ganges Indian and Chinese systems of this period bear resemblance to the early modern European Westphalian system with their even distribution of capability among the major contestants and emphasis on balance of power, the Greater Near Eastern system and the Carthaginian system are sharp contrasts with their extremely high concentration of capability within the hands of the imperial powers.

\section{Light Cavalry}

The use of iron in production allowed agriculture to spread to heavily forested areas and expanded the domain of civilizations. Consequently, the Chinese, Ganges Indian and Greek civilizations emerged. From around 800 BC to 200 BC, China, Ganges India and Greece generated splendid cultural achievements. This is referred to as the classical golden era in human civilization, or the Axial Period. In "Navigating world history," Manning (2003) comments on Jaspers (1949):

"He defined "the Axial Period" (centering on 500 B.C.E. and including the three centuries on either side of that date) as a time of breakthrough in knowledge and faith, with insights that were never to be exceeded until the present day. This was the time of Confucius and Lao Tzu in China, of Buddha and the authors of the Upanishads in India, of Elijah and Jeremiah in Israel, and of Homer, Plato, and Thucydides in Greece. Jaspers sought the cause of the axial moment that he observed: he rejected the assertion of Alfred Weber that it had resulted from the influences of Indo-European horsemen dispersing across Eurasia, and concluded instead that it resulted from 'many small States and small towns: a politically divided age engaged in incessant conflicts; ... questioning the previously existing conditions.'" (51) 
Jaspers (1949)'s conclusion on the cause of the splendid achievements of the Axial Period agrees with the main arguments of this book.

During the same period, however, the Greater Near Eastern region-the early leader in human civilization for more than two millennia-stagnated and fell behind. Around this period, the use of iron weapons and horses, first in horsedrawn war chariots and then in light cavalry units in warfare, raised the economies of scale in conflict for the Eurasian world. These military technological innovations facilitated the rise of combined arms legions with light infantry and light cavalry supplying the bulk of the fighting force, thus increasing the mass factor in warfare. ${ }^{68}$ Warfare became more mobile, decisive and destructive. The core of the Assyrian army had been war chariots, but by the time of the Neo-Assyrian Empire, light cavalry had replaced the chariots. Wars with the Persians, who used light cavalry, had prompted the Neo-Assyrian Empire to reform its military and to rely more on light cavalry instead of the more cumbersome horse-drawn war chariots.

The more mobile, decisive and destructive form of warfare caused by the use of light cavalry and combined arms legions composed of light infantry enlarged the mass factor and caused greater disparity in the distribution of resources and capability within the Greater Near Eastern world. This new form of warfare ended the comfortable security of Egypt in international politics. From around $1000 \mathrm{BC}$ onwards, foreign invasions of Egypt were more probable and frequent. In 712 BC the Nubians invaded Egypt to establish the $25^{\text {th }}$ dynasty. They were supplanted by the Assyrians, who occupied Egypt between $671-$ 651 BC. In around 605 BC, the Neo-Babylonians then defeated and captured Egypt, before the Achaemenid Persians took their turn with a further conquest of Egypt in 525 BC.

The Persians, who pioneered the use of light cavalry, finally conquered Mesopotamia and Egypt during their Achaemenid Dynasty. Persian warriors formed the core of the Achaemenid standing army. The army relied heavily on light infantry and light cavalry units, although there were also a small number of obsolete war chariots, fielded by the aristocrats. Occasionally, there were small numbers of camel-borne troops and war elephants present as well. The light cavalry was the most important branch of the Achaemenid army, instrumental in conquering far-flung subject lands and remained important until the last days of the Achaemenid Empire.

In China, Greece and Ganges India, the increase in the economies of scale in warfare associated with these military technological changes intensified competition within these diverse international political systems without destroying

68 Refer to Dudley (1992). 
the city-state or territorial state systems. The distribution of capability within these systems remained highly even within this period. Consequently, in the Chinese, Greek and Indic systems, the positive scaling effect of a larger mass factor dominated the negative unbalancing effect and the relativist concern increased. Furthermore, the largely even distribution of capability within the Chinese, Greek and Indian systems prevented the emergence of extremely risk-averse or risk-seeking power-induced risk attitudes with their associated distortions. Therefore, within these systems, economic and developmental performance improved.

In the Greater Near East, these military technological changes had very different effects on geopolitics and economic performance. In the Greater Near East, the greater economies of scale in warfare caused a concentration of resources and military capability in the hands of the imperial regimes of the Neo-Assyrian Empire, the Neo-Babylonian Empire, and the Achaemenid Persian Empire. The increase in the asymmetry of relative capability reduced relativist concerns. The increase in the economies of scale in warfare caused a further reduction in relativist concern. The great asymmetry in distribution of capability within the Greater Near Eastern system also generated an extremely risk-averse power-induced risk attitude. Consequently, in the Greater Near East, creativity and economic performance faltered.

In the Western Mediterranean basin, besides the above military technological changes, the rise of gigantic naval fleets due to the use of triremes also increased the economies of scale in warfare. There was a high concentration of resources and capability in the hands of Carthage, a great maritime power strategically located at present-day Tunisia. Consequently, there was also a low relativist concern and a highly risk-averse power-induced risk attitude there and therefore a low level of innovation and developmental effort.

In sum, the same military technological changes had very different effects on the international political structure and developmental performance of the classical civilizations of China, Greece, India, Carthage, and the Greater Near East. The following sections will analyze each civilization in detail and will especially compare classical Greece with the Carthaginian Empire to study the effect of international political structure on developmental performance.

\section{The Middle East}

From the dawn of the first civilization to around the establishment of the Achaemenid Persian Empire in 525 BC, Middle Eastern leadership in human civilization had been unchallenged. The Near East had always been the most advanced region in the world for over three millennia. The Near East bestowed 
upon the world the first writing system, the first city and the first law codes, to name just a few. But during the Axial Period the Near East was overtaken by the classical civilizations of Greece, Ganges India and China as the pacesetters in human civilization.

During this period when leadership in human civilization shifted, there were a series of pan-Middle Eastern empires that conquered the whole of the Near East, Egypt and beyond. First was the Neo-Assyrian Empire, followed by the Neo-Babylonian Empire and the Achaemenid Persian Empire. The Neo-Assyrian Empire briefly occupied Egypt, from 671-651 BC. The Neo-Babylonian Empire controlled Mesopotamia, Egypt and parts of Persia, though its reign was short, from 604 BC to 562 BC. In 539 BC, Babylon itself was conquered by the Persians, and the Achaemenid Persian Empire soon became the largest of the pan-Near Eastern empires and the largest empire thus far in history. In sum, from around $700 \mathrm{BC}$, the Middle East was effectively governed by a series of universal empires.

Military technological changes drove the aforementioned structural changes in the Greater Near Eastern international political system. The use of iron weapons and the rise of light cavalry led to the emergence of combined arms legions where light infantry supplied the bulk of the fighting force and the light cavalry was the important mobile striking force. There was an increase in economies of scale in warfare associated with these military technological innovations as warfare became more deadly and mobile.

In the Greater Near East, there was a dominant core area in the form of the Fertile Crescent at the center, with the Nile Valley on the west and the western part of the Iranian Plateau on the east. Consequently, there was substantial asymmetry in combined relative economic and military efficiency in favor of the power controlling the dominant core area. The combined effect of the greater economies of scale in warfare and the more asymmetric combined relative economic and military efficiency generated a very high asymmetry in the distribution of capability and resources. The military technological changes therefore transformed the Greater Near Eastern system from a multi-polar pluralistic international political system into an imperial order with resources and military capability highly concentrated in the hands of the imperial authority.

The largest of these pan-Greater Near Eastern empires, the Achaemenid Persian Empire, actually expanded until reaching its natural boundaries. Several ancient seats of Middle Eastern civilizations, including Mesopotamia, the Indus River Valley, and the dry arid landscape of Egypt, were united under its rule. These were regions that were highly advanced economically and densely populated with terrains suitable for conquests by the Persian light cavalry and light infantry legions. Beyond the empire, to the east were the dense forests of the verdant Ganges river valley of India; to the west were the Mediterranean 
Sea and the mountainous maritime geography of Greece; to the south were the Arabian and Sahara deserts; and to the north was the sparsely populated Eurasian Steppe. These were regions that either had terrains unsuitable for the military operations of the Persian light cavalry and light infantry legions or were unimportant economically and therefore not worth the effort of the empire to acquire. The empire reigned from 557-300 BC and there was no serious challenger to its supremacy.

Many will read "no serious challenger" and immediately think of the Spartans and other Greeks at Thermopylae. The victories of the Greeks over the Persians in the Greco-Persian Wars (499-449 BC) are indeed much recounted and celebrated in the Western tradition, for upon them hinged the survival and continuity of Western civilization. Yet, these battles were of no central concern to the Persians. These defeats undermined neither the rule of the empire nor its proper function: the rule of the Achaemenid Empire over the oriental provinces of Persia, Mesopotamia, Anatolia, Syria and Egypt was never threatened. These provinces were of much greater significance (than any small Greek city-state) to the health of the Persian Empire. Pastoral nomads of Central Asia, including the Scythians who resided around the Aral Sea, were persistent intruders. But they were merely irritants. They posed no serious threat to the wellbeing and survival of the all-powerful empire. Successfully presenting itself as vicegerent of the supreme deity Ahura Mazda on earth, the Achaemenid regime was almost uncontested from within as well as without. Revolts were rare and the imperial family's dominance was never challenged until the invasion by Alexander the Great.

The increased size of the mass factor generated extreme asymmetry in the distribution of resources and capability within the Greater Near Eastern international political system. The aggravated asymmetry in distribution of capability blunted political and military competition within the system, and lowered relativist concern. Moreover, given the highly concentrated distribution of capability induced by the military technological changes, the enlarged mass factor itself further dampened political-military competition and lowered relativist concern. Consequently, the series of pan-Middle Eastern empires, including and culminating in the Achaemenid Empire, had a very low relativist concern, given the almost nonexistent international political-military competition. Inevitably, development in economic and cultural fronts suffered. The great asymmetry in distribution of capability within the Greater Near Eastern system caused not just complacency in developmental efforts. It also generated an extremely risk-averse power-induced risk attitude, given the increased size of the mass factor. Consequently, in the Greater Near East, imperial complacency and conservatism prevailed and creativity dissipated.

This era of the pan-Middle Eastern empires of the Neo-Assyrian, Neo-Babylonian and Achaemenid Persian Empires, covering the period of roughly 
700-300 BC, sees imperial regimes promoting the diffusion and mixing of cultures and effectively ended the isolation of the old civilizations. Yet, the weight of the successive empires stalled the developmental momentum in these old seats of civilization and the economy of the region slowly declined. Furthermore, in sharp contrast to the bursts of innovation found in the earlier era of a more pluralistic international political structure, the Greater Near Eastern world could boast of few major advances during this era of inertia. ${ }^{69}$

On the other hand, the adjacent areas of mountainous maritime Greece and the verdant Indian Ganges valley, as well as the more distant South India and even more remote China, were developing under their respective city-state and competitive territorial state systems and were bringing forth their classical civilizations with the representative figures of Socrates, the Buddha and Confucius. ${ }^{70}$ These late-starter civilizations soon began to catch up with and even surpass the Middle East, whose ancient leadership in civilization disappeared. This happened despite a universal peace and other conveniences accorded by the Neo-Assyrian and the Achaemenid Persian imperial orders. ${ }^{71}$

\section{Greece and Carthage}

Greece is highly fragmented geographically. Greece has about 3,000 islands, including the famous islands of Crete and Rhodes. The mainland contains multiple mountain ranges that split the country into many peninsulas and isolated regions, including the Peloponnesus Peninsula. The fragmented geography encouraged localism in politics during antiquity. During the classical era, the dominant political units in Greece were the poleis - independent city-states of which the more famous and important include Athens, Sparta, Corinth and Thebes.

Another important geographical feature of Greece is its intimacy with the sea. Socrates the Greek philosopher commented that "We live around the sea, like frogs around a pond." Greece has an extended coastline of over 15,000 kilometers; no point on the Greek mainland is farther than 100 kilometers from the sea. Due to the close proximity to the sea, the classical Greeks were a seagoing people with extensive trading networks and colonies in the Black Sea and western Mediterranean regions. The existence of extensive and far-flung Greek overseas colonies which were politically independent from their mother

69 Refer to Wesson $(1967,1978)$.

70 Refer to Haywood (1997, pp. 22-23).

71 Refer to Stavrianos (1982, Part II). 
cities made concentration of capability even harder and caused further fragmentation in Greek politics.

After slowly recovering from the Greek Dark Ages of ca 1200-800 BC, citystates began to emerge in Greece around 900-800 BC. In addition, around 800 BC the main period of Greek overseas expansion also began. The use of iron implements facilitated the spread of agriculture into harsher terrain, and the advances in agriculture aided the resurgence and extension of the civilization.

The use of iron spread into warfare and created an infantry revolution around 700-650 BC, which saw the rise of the phalanxes or the heavy infantry legions. A Greek phalanx was a close formation of heavily armored infantrymen specialized in prolonged combat. These infantrymen were named hoplites after their shield Hoplons (a large circular shield covered with a bronze sheeting), the hoplites were armored typically in a leather cuirass (although some wore a bronze cuirass or no armor at all), the Corinthian helmet further supplemented by greaves. The weapon of a hoplite was a weighted spear called the Dory. The phalanx formation organized these heavily armored infantry into a bronze shield wall, which during this period was the dominant infantry doctrine. Sparta took the lead in developing the phalanx through its rigorous training regimes creating a fully professional force of hoplite soldiers. Sparta dominated the Peloponnesian Peninsula around 650 BC, at a time when written law codes were being created. This infantry domination of warfare covers the period ca $500 \mathrm{BC}$ $300 A D$, which roughly (and not coincidentally) corresponds to the time from which the ancient Greeks began to unify their city-states and conduct largescale battles, to the dissolution of the Western Roman Empire 800 years later.

Greek phalanxes were renowned for their mass and might throughout the Near East and the Mediterranean region. Consequently, many Greek soldiers served as mercenaries for Persian governors. The military technological changes increased the economies of scale in warfare. Politics and wars increasingly involved larger alliance systems and empires. Given the fragmented mountainous and maritime terrain, mounted soldiers initially played a relatively minor role in Greek warfare (this later changed under the leadership of Philip II of Macedon who pioneered combined arms of cavalry and infantry formations). Military tactics in the Greek city-state system era took advantage of infantry mass envelopment and flanking maneuvers.

The greater economies of scale in warfare favored larger political units. Relatively large states or empires, encompassing stretches of settled civilized societies with their dense population and high level of material wealth, have the benefit of being able to field large numbers of battle-efficient legions. There was within Greece, therefore, a trend towards ever larger political organization in either the form of military alliances or large territorial states or empires. This trend toward larger political units culminated in the Macedonian dominance of Greek politics from ca 350 BC. 
Macedonia, under King Phillip and Alexander the Great, pioneered the use of combined arms warfare with heavy infantry at its core. Phillip increased the training and importance of cavalry on the battlefield, but the cavalry was to work in tandem with the Macedonian phalanx. Phillip of Macedonia further supplemented the destructive power of the Greek heavy infantry by incorporating missile auxiliaries, well trained light infantry (hypaspists) and siege equipment. The combination of the revolutionized Macedonian phalanx, strong cavalry formation, elite light infantry supplemented further with siege corps resulted in more decisive battles and campaigns. The organizational and tactical innovations of Phillip of Macedonia were fully and boldly exploited by his son Alexander the Great first to subdue the Greek city-states and then to take on the Achaemenid Persian Empire. The lethargic Persian Empire had been too thoroughly plagued by imperial complacency and conservatism and was not in a position to react decisively and successfully to the sudden emergence of threat due to these military innovations. It was swiftly overrun and conquered by Alexander the Great.

There was a military revolution in the navy as well. The use of triremes resulted in the formation of specialized and unprecedented war fleets. Economies of scale in naval warfare became larger, making naval warfare more expensive. The greater financial requirement contributed to the consolidation of city-states into large alliances and empires, and Athens became the premium Greek naval power. ${ }^{72}$ These two military revolutions, on land and sea, enabled the Greek city-states to defeat the Persian Empire in the Greco-Persian Wars: the Persian light infantry were no match for the densely packed and heavily armored Greek phalanxes. These military revolutions also began a trend towards larger political organizations in the Mediterranean basin, the apex of which was the Roman Empire.

The polis as a form of political organization signified the maturing of Greek societies and the ability to tap and mobilize resources for increases in scale in warfare, land or sea. Yet, creating a navy, manning its vessels, and replacing worn-out warships at least every 20 years required the resources and manpower of much larger communities than Athens, Corinth, or Sparta. Therefore, some form of pooling of interstate resources was almost essential for any Greek strength at sea. The Greek city-states ultimately proved too small to exploit the greater economies of scale in warfare generated by the new military technology. Consequently, the fragmented classical Greece city-state system was replaced by the empire of Macedonia.

During the long existence of the Greek city-state system, the isolated and fragmented geography of Greece caused the city-states to be fairly equal in

72 Refer to Starr (1989, pp. 50-66). 
terms of relative combined military and economic efficiency. In other words, the classical Greek international political system was pluralistic and had a highly even distribution of resources and capability. Political-military competition was a constant fact of life in the classical Greek system and relativist concern was high.

The military revolution on land and at sea resulted in an increase in the size of the mass factor. Yet, given the highly symmetrical relative combined military and economic efficiency and very even distribution of resources and capability, the enlarged mass factor generated basically no greater asymmetry in distribution of capability and produced hardly any negative unbalancing effect and almost only a positive scaling effect. Relativist concern was significantly raised. The military revolution of heavy infantry and large war fleets heightened political-military contests among the Greek city-states and prompted them to greater achievements and state power. Furthermore, the highly even distribution of capability in the Greek system ensured that a largely moderate power induced risk attitude prevailed. There was no serious distortion in economic decisions or allocation of resources caused by severe risk-seeking or risk-averse power-induced risk attitudes. Consequently, the Greek international political-military environment was highly salubrious to creativity and development.

The most outstanding achiever of classical Greece was Athens. Despite being almost constantly at war, like other Greek city-states, Athens flourished culturally, economically and politically in the $5^{\text {th }}$ century BC. Athens dominated the Eastern Mediterranean and Black Sea trade and owned silver mines. Buzan and Little (2000, p. 200) note that: "Athens, for example, imposed a single currency and standardized weights and measures on the other citystates within its empire (Meijer and Van Nijf 1992: 33-51)." Democracy developed alongside an exceptional outburst of cultural confidence and creativity, in Greece as a whole and Athens in particular. Vase-painting, sculpture and drama reached new heights. A great public building program began: the city, and notably the Acropolis were rebuilt and the classical style of art and architecture matured..$^{73}$ Many of the most important authors of Western culture were products of this period. These include the dramatists Aristophanes and Sophocles; the philosophers Socrates, Plato and Aristotle; and the historians Herodotus and Thucydides.

Rivalry among the Greeks and the completely Hellenized Macedonia propelled Greek achievements in the economic, cultural, political and military arenas to new heights. ${ }^{74}$ Herodotus completed his History in $430 \mathrm{BC}$; Pheidias

73 Refer to Haywood (1997, pp. 82-83).

74 Refer to Bernholz (1998, pp. 109-114) in Bernholz et al. (1998) and Ungern-Sternberg (1998, pp. 85-107). 
and Polyclitos produced their sculptures and brought art to new heights; Democritos developed an atomic theory of matter; Thucydides wrote The History of the Peloponnesian War; Socrates taught his philosophy; and Plato and Aristotle founded their schools, to name but a few of the cultural achievements of the time.

After the Macedonian conquest of the Persian Empire under Alexander the Great, Greek cultural influence spread throughout the classical world. Classical Greek became the lingua franca. Political and military competition of the pluralistic Hellenistic international political system further propelled the development of the classical era. (Remember that, after the death of Alexander, his empire divided and the pluralist Hellenistic system emerged from it.) The Hellenistic Age (336-31 BC) generated extraordinary economic and scientific achievements. ${ }^{75}$ Alexandria, the capital of Ptolemaic Egypt, became the largest and richest city in the world, and came to overshadow Athens as a cultural center. Around 105 BC, a college of technology was founded at Alexandria. Science made important advances: Aristarchus first proposed a heliocentric universe around $270 \mathrm{BC}$; Eratosthenes measured the Earth's circumference around 235 BC; Euclid of Alexandria wrote the famous "Elements" on geometry which is one of the most influential works in the history of mathematics and remained the main textbook until at least the late $19^{\text {th }}$ century. These achievements, under first the Greek city-state system and then the Hellenistic state system, were collectively known as the Greek Miracle.

Stavrianos (1982) comments on the relationship between the international political competition and the technological achievements of the classical world:

"Significantly enough, it was only war that could arouse the classical civilizations from their technological lethargy. The Greeks invented ingenious ratchet-equipped catapults and wheeled assault towers pulled by block and tackle." (184)

The comment of Stavrianos (1982) agrees with the main argument of this book that political military competition propels creativity and economic development.

The splendid achievements of classical Greece contrasted sharply with the unmemorable performance of the nonetheless mighty Carthaginian Empire. The Carthaginian Empire flourished from around 800-264 BC (the year of the First Punic War). Carthage, a Phoenician colony, had been established

75 Refer to Stavrianos (1982, pp. 98-102). 
ca 814 BC. $800-600$ BC was the main period of Phoenician and Greek colonization in the western Mediterranean region. The Carthaginian system had the upper hand in the western Mediterranean region: around $580 \mathrm{BC}$ the Carthaginian Empire defeated Greek settlers at Lilybaeum (Sicily), and in 539 BC an Etruscan-Carthaginian force expelled the Greeks from Corsica.

The Carthaginian Empire was the first true maritime empire in ancient times. By 500 BC the Carthaginians were the dominant force at sea in the Western Mediterranean, whilst the Persians dominated the eastern waters. ${ }^{76}$ The Carthaginian Empire largely dominated the seas and coastal areas of the western Mediterranean region until the Punic wars. As a commercial naval empire, the Carthaginian Empire had practically expanded to her natural boundaries. Encompassing Corsica, Sardinia, the Balearic Islands, Morocco, Algeria, Tunisia, the western part of Sicily, the southeastern part of Spain, and the western part of Libya, Carthage had no worthwhile rival in the Western Mediterranean basin. The Carthaginian Empire's economic might depended on trade. The height of its dominance in the Western Mediterranean occurred between 600-500 BC. At the peak of its power, Carthage ruled over 300 other cities around the western Mediterranean basin and was the leader of the Phoenician world.

In the Western Mediterranean basin, Carthage reigned supreme. Carthaginian naval mastery in the Western Mediterranean world was unquestioned until the third century $B C$, but this power was in fact the cause of its mediocre developmental achievements. ${ }^{77}$ Toutain, in his book The Economic Life of the Ancient World (Economie Antique) (1930) affirms Carthaginian trading and agricultural achievements but comments that Carthage only achieved economic success, with no concomitant political, intellectual or ethical achievements. Given its secure external environment, the Carthaginian Empire was a loose, superficial network of business and naval bases and maintained no centralized state machinery.

The Carthaginian Empire was very secure because of the almost total absence of political-military competition-until the Punic Wars. Relativist concern was low and there was a lack of drive for greater development. Both the naval revolution associated with the use of triremes and the heavy infantry revolution associated with the rise of phalanxes increased the mass factor. Given the extreme asymmetry in distribution of resources and capability in the Western Mediterranean basin, the enlarged mass factor furthered dampened political-military competition in the Carthaginian system and lowered relativist concern, since the negative unbalancing effect dominated the positive scaling

76 Refer to Starr (1989, pp. 25-28).

77 Refer to Starr (1989, p. 54). 
effect. Moreover, the high concentration of capability and the large mass factor generated a highly risk-averse power-induced risk attitude which severely distorted economic decisions and especially inhibited creativity.

A comparison between the Carthaginian Empire and the Athenian Empire reveals that although the Carthaginian Empire ruled much longer and was more powerful, its memorable achievements pale in comparison to those of the Athenians, who were driven by the competition from other Greek city-states to excel and achieve. Pericles, in his famous funeral oration commemorating the Athenian soldiers who had fallen in battle against Sparta in $431 \mathrm{BC}$, exclaimed: "to sum up: I say that Athens is the school of Hellas......" ${ }^{18}$ If one contrasts the geographical sphere of influence of the Greeks with that of the Carthaginians, then one finds that the Carthaginian Empire had about the same sphere of influence from the Achaemenid Persian era through to the time of the first Punic war, while the Greek city-state system expanded to almost the whole of the classical world during the Hellenistic Era. This is yet another piece of evidence for the stark difference in achievements and development drive between pluralistic Greece and imperial Carthage. A simple list of famous names can perhaps sum up the difference: asked to name famous Carthaginians, few could probably remember more than Hannibal; but how many ancient Greeks could be named?

\section{India}

The earliest civilization of India was the Bronze Age civilization of the Indus River valley. It collapsed around the beginning of the second millennium BC and never recovered. Little is known about the history of this civilization. Later, from ca $1500 \mathrm{BC}$ to $500 \mathrm{BC}$, came the Vedic period in Indian history. This era saw the spread of Indo-Aryan civilization across the whole of northern India, especially the Gangetic Plain. City-states began to emerge around 1000 BC in the Ganges River valley and also southern India. By 900 BC small tribal kingdoms and aristocratic tribal republics, known collectively as janapadas, were developing across the Ganges plain. By 700 BC, by means of agrarian extension, control of trade routes and a new and more aggressive type of warfare partly caused by the use of iron weapons, they had consolidated to form sixteen mahajanapadas (that is, great realms). ${ }^{79}$ From 540-490 BC, Magadha, under its energetic king Bimbisara, had emerged as the most powerful mahajanapada.

78 Refer to Jowett (1999, pp. 35-46).

79 Refer to Kulke and Rothermund (1998, pp. 33-49). 
The Indo-Aryan civilization centered on the Ganges River valley. The Ganges River has many tributaries, and its basin covers an extensive area in northern India. Unlike the arid Indus river valley, the Ganges region has high precipitation rates. Densely forested during ancient times, the harsh terrain of the Ganges Basin was a difficult barrier for ambitious conquerors. The extreme humidity and heat of the Indian summer deterred foreign conquerors like Alexander the Great, Genghis Khan and Timurlane. The hostile terrain helped in the maintenance of the initial city-state system and subsequently the territorial state system. Indian political geography was therefore highly fragmented during the formative period of the Ganges Indic civilization.

Another important region of the subcontinent is the mountainous southern India. Southern India is dominated by the Deccan Plateau. In southern India, mountain ranges and rivers running west to east break up the region into many isolated compartmentalized localities; political unification was even harder to achieve and maintain in southern India than it was in the north. The existence of highly fragmented southern India meant that even if an imperial power controlled the Indo-Gangetic Plain, it was still difficult for the imperial regime to control peninsular southern India. ${ }^{80}$ Consequently, it was more difficult for an imperial order that covered the whole civilization to emerge and survive in India than it was in the Middle East or China.

Given the fragmented geography, with the exception of the brief unification under the Mauryan Empire, the Indian subcontinent was fragmented politically throughout antiquity-indeed, the unification of the subcontinent is historically quite a recent phenomenon. The absence of a dominant core area meant that relative combined military and economic efficiency among the many contestants was fairly symmetric. The fragmented geography also meant that with the same military technology, the mass factor was smaller in India than in China or the Middle East. A fairly symmetrical relative combined military and economic efficiency and a small mass factor resulted in a fairly even distribution of resources and capability among the many political-military contestants of the Indian system. The fairly even distribution of capability also meant that there was no extremely risk-averse or risk-seeking power-induced risk attitude to severely distort economic decisions. Consequently, the high relativist concern of this period in India generated good developmental performance.

During this period there was widespread commercial development, political and cultural reforms, as well as religious reformation and counter-reformation. ${ }^{81} \mathrm{Hand}$ in hand with the process of state formation was the growth of

80 Refer to Kulke and Rothermund (1998, pp. 9-12).

81 Refer to Stavrianos (1982). 
cities and great development of religions. This was the formative period of the Hindu religion. The late $6^{\text {th }}$ century $B C$ also witnessed the lives and teachings of Mahavira, the founder of Jainism and of Siddhartha Gautama, the Buddha. There was geographical expansion of the Gangetic Indic civilization as well. By 500 BC the Indic civilization extended as far south as the Godavari River, covering the whole of northern India. ${ }^{82}$ There was use of standardized weights and emergence of scholars such as the great linguist, Panini. ${ }^{83}$

The application of iron weaponry from the $7^{\text {th }}$ century BC increased the scale of warfare and led to the use of large infantry legions; around $500 \mathrm{BC}$ elephants were introduced into warfare alongside massive light infantry legions. A strong fiscal capacity of the state was required to finance the larger and more expensive war machine. ${ }^{84}$ On the size of the military, Kulke and Rothermund (1998) notes that:

"Greek and Roman authors report that the Nandas, who had their capital at Pataliputra when Alexander the Great conquered northwestern India, had a powerful standing army of 200,000 infantrymen, 20,000 horsemen, 2,000 chariots drawn by four horses each, and 3,000 elephants. This is the first reference to the large-scale use of elephants in warfare. Such war elephants remained for a long time the most powerful strategic weapons of Indian rulers until the Central Asian conquerors of the medieval period introduced the new method of the large-scale deployment of cavalry."(56)

The new form of warfare had a large mass factor. The increase in the size of the mass factor generated more intense political-military competition. Given that there was a fairly even distribution of capability, the larger mass factor generated a positive scaling effect that dominated the negative unbalancing effect. The consequence was to raise relativist concern and to further propel development in the Indian subcontinent. Moreover, there was no extreme riskaverse or risk-seeking power-induced risk attitude, given the fairly even distribution of capability. The heightened relativist concern was therefore translated into creativity and greater developmental effort without much distortion.

These military innovations increased the economies of warfare and spurred the consolidation of city-states into the mahajanapadas. Diffusion of knowledge of Persian imperial administration helped to increase asymmetry in relative combined economic and military efficiency in favor of the strongest contestant. The enlarged mass factor, together with the aggravated asymmetry in

82 Refer to Haywood (1997, pp. 100-101).

83 Refer to Kulke and Rothermund (1998, pp. 50-53).

84 Refer to Kulke and Rothermund (1998, pp. 55-57). 
relative combined military economic efficiency, generated the short-lived unification under the Mauryan Empire, when exceptionally ambitious and capable leaders emerged in the scene.

The Mauryan universal empire ruled briefly from 322-185 BC as a centralized state. ${ }^{85}$ Ashoka, a Mauryan Emperor, imposed the Buddhist doctrine of right conduct throughout the empire. That period also saw the beginning of the Hellenistic Era, brought in by Alexander and his conquests. The work of Chanakya Kautilya, the Arthashastra, was the culmination of the art of statecraft of the ancient Indian civilization. Mauryan imperial rule however was extremely short. It effectively lasted only three generations- from Chandragupta to son Bindusara and grandson Ashoka. The empire collapsed soon after the death of Ashoka. So, the developmental drive of the pre-Mauryan pluralistic international political order was not choked off. The momentum was retained and reinforced during the subsequent period to create the classical golden age of India.

\section{China}

The recorded history of the Chinese civilization begins with the Shang Dynasty, which reigned from around $1600-1066 \mathrm{BC}$ as the first urbanized culture of China. (The earlier Xia Dynasty, 2100 to 1600 BC, has no recorded history; what historians know about the Xia is mainly through mythology.) The power of the Shang Dynasty was quite limited as it covered only the middle and lower stretches of the Yellow River valley: there were many rival states and tribes both within its territory and beyond its border. The Shang Dynasty was overthrown by a tribal alliance from the west around 1066 BC, and that tribal alliance installed the Zhou Dynasty.

The territory or sphere of influence of the Zhou Dynasty was quite limited as well and was only slightly more extensive than that of the Shang Dynasty. For example, the Kingdom of Chu in the valley of the Han River (a tributary of the Yangtze River) did not yield to the authority of the Zhou Dynasty, and the Zhou regime was unable to alter the situation. There were also many independent non-Chinese states or tribes yet to be pacified within the sphere of influence of the Zhou Dynasty. The Chinese system of the time was held together more by common culture, blood ties and identity, rather than through political organization or military might. Governance was based on personal, familial

85 Refer to Kulke and Rothermund (1998, pp. 58-59). 
or tribal ties - the ideal politics of Confucius. In many parts of ancient China, tribes rather than states were the dominant form of political organization.

The history of the Zhou Dynasty can be divided into two eras: the Western Zhou Dynasty (1066-771 BC) and the Eastern Zhou Dynasty (770-256 BC). By the time of the Eastern Zhou Dynasty, the growing power of the larger peripheral vassal states of Zhou had already overshadowed the authority of the central government. In turn the reign of the Eastern Zhou Dynasty can be subdivided into two eras: the Spring and Autumn Era, and the Era of the Warring States.

During the Spring and Autumn Era, military rivalries between the vassal lords became more intense and the authority of the Zhou Dynasty dwindled to almost nothing. This era was also known as the Era of the Five Hegemons. Wars became more frequent and were of larger scale, with smaller states annexed on a frequent basis. The number of states declined as reorganization occurred to wipe out smaller and weaker states. At the beginning of the Spring and Autumn Era, there were more than a hundred principalities. By the Warring States Era, this had dwindled to about a dozen, seven of which were the major powers.

The intense political-military competition generated high relativist concern. Furthermore, given the fairly even distribution of capability, there was no extremely risk-averse or risk-seeking power-induced risk attitude to distort economic decisions. Consequently, there were many reform efforts in the cultural, economic and social arenas, all seeking to harness greater power for the state in international political-military competition. The famous statesman, Guan $\mathrm{Zi}$, for instance, was a product of the Spring and Autumn Era. Guan Zi (725-645 BC), who is also referred to as Guan Zhong, was a merchant who entered politics to become the prime minister of Duke Huan of the Dukedom of Qi. His reforms, many of which were mercantilist in nature, propelled the Dukedom of Oi to hegemony. Similar reforms were undertaken in the other states, especially the subsequent hegemonic powers.

China had a very pluralistic and competitive international order during the Era of the Five Hegemons and the succeeding Era of the Warring States. Given the highly even distribution of capability, there was no extreme risk-averse power-induced risk attitude to hold back the creativity or to distort the economic decisions of the rival states which were eager to increase their power. Consequently, the harmony offered by a common culture and identity of the earlier period broke down and traditional beliefs were questioned. Many philosophic schools blossomed. The phenomenon was referred to as "the hundred schools of philosophy". This was an era of great cultural, economic and political experiments and achievements which laid down the foundations of the Chinese civilization and state. ${ }^{86}$

86 Refer to Hui (2005) for a comparison between the classical era Chinese competitive state system and the early modern European competitive state system. 
The subsequent Era of the Warring States saw a great increase in large-scale warfare, the emergence of larger states, and a more centralized form of government with huge professional bureaucracy. The increase in the economies of scale in warfare was due to the rise of massive light infantry legions and light cavalry, in place of the horse-drawn war chariots used by the early Zhou Dynasty. Selective breeding had made possible more-powerful horses that could carry riders, rather than just pull chariots; technological advances such as the use of iron weaponry and crossbows made massive infantry legions the dominant fighting force on the battleground. The result was a form of warfare that was more mobile, deadly and decisive.

Given that the Chinese international order was highly pluralistic and relative combined economic and military efficiency was highly symmetrical, the distribution of resources and capability was fairly even among the major contestants. Consequently, the enlarged mass factor generated a mainly positive scaling effect which dominated the negative unbalancing effect. Political-military competitions among the contesting states were intensified. To be less efficient and powerful had dire consequences. There was therefore heightened relative concern which further pushed on development in many areas. Culturally and economically, this was a very productive and prosperous era. Political development during this period was spectacular too.

This period witnessed the further consolidation of the centralized bureaucratic states which had started in the Spring and Autumn Era. Every state undertook institutional changes in order to tap and utilize resources they controlled more efficiently, all so as to be able to compete in the international arena. The aristocracy lost their dominance of the military, which out of necessity became professionalized-as did the bureaucracy. The world-famous "The Art of War" by Sun Tzu was written during this era as were a myriad of other less famous works on military science. ${ }^{87}$

Intense interstate rivalry during this era prompted states to undertake reforms to advance their economy and to strengthen their state capacity. Many of the philosophy schools taught measures to enhance state strength. The Legalist school especially had this as its professed objective and advocated draconian measures to increase the economic, fiscal and military strength of the state. ${ }^{88} \mathrm{~A}$ good indicator of the economic might and state capacity of the era was the length and scale of wars conducted. It was common for participating states to mobilize hundreds of thousands of soldiers, or even close to a million troops, and fight over extensive territory for months or even years. This

87 Refer to Sawyer (1993).

88 Refer to Fung (1966) and Bodde and Fung (1983). 
could not have happened without a very high degree of economic achievement and fiscal strength. ${ }^{89}$

Many of the reform measures undertaken by the contesting states were pioneered and advocated by the already-mentioned Legalist school. The Legalist school of thought strongly advocated institutional reforms to enhance state capacity. The Legalists taught statecraft to princes and strongly supported the centralization of state administration. The basic institutional structure of the traditional Chinese state was laid down during this era, largely following the institutional structure of the Kingdom of Oin: the kingdom of the First Emperor who united China.

The Kingdom of Qin rose to military and political dominance after Lord Shang, a leading Legalist scholar, overhauled its institutions. The reforms undertook by Lord Shang made the state of Qin a powerful, centralized war machine. The new institutions installed included the centralized provincial-county system (replacing the feudal regime of the early Zhou Dynasty), the draconian penal code, and the professional bureaucratic and military organization of the central government.

During this period, one of the two most important developments in Chinese legal history took place: the writing of Fa Jing (Canon of Laws) by Li Kui of the Kingdom of Wei in 542 BC. (The other was the issuance of Kaikuang Lu (Kaihuang Code) by Yang Jian, the founding emperor of Sui Dynasty). ${ }^{90}$ Although there were earliest publications and codifications of laws, such as those undertaken by premier Zi Chan of the Kingdom of Zheng during the Spring and Autumn Era, the work of Li Kui laid the basic framework for the legal institutions of China for the next eight to nine centuries. The legal systems of the Oin, Han and Jin dynasties basically followed the work of Li Kui.

Intellectual achievements were no less amazing. Almost all the major Chinese philosophic schools of thought had their origin in this period of great political turmoil and competition. The four major schools were Confucianism, which became official orthodoxy in imperial China, the statist Legalism whose teachings laid the foundation for the unification of China under the First Emperor, the pacific Moism and the naturalist philosophical Taoism..$^{91}$ Other minor schools included the Yin-yang school that theorized about cosmic forces and the basic elements of the universe, the logicians who focused on definition and logic, the school of agriculture that emphasized and promoted farming, the school of diplomacy that specialized in diplomatic politics and the school of

89 In contrast, the first war of such scale in the Western world was the Napoleonic wars of Europe.

90 Refer to Head and Wang (2005).

91 Refer to Fung (1966) and Bodde and Fung (1983). 
military that studied warfare and strategy. There was such a burgeoning of intellectual inquiry that Chinese historians refer to the intellectual achievements of this era as the Hundred Schools of Philosophy.

Another piece of evidence testifying to the vigor of this era was the energetic geographic expansion of the Chinese sphere of influence. Almost all of the traditional areas occupied by the Han Chinese were explored and conquered during this era. The southern part of the Manchurian plain was conquered by the Kingdom of Yan. The Kingdom of Zhao pushed back the nomadic tribal alliance of Xiongnu and annexed Inner Mongolia. The Kingdom of Chu extended its administration all the way to what is Yunnan province today. The Kingdom of Oin acquired the Gansu and Sichuan provinces. The boundaries of the traditional Chinese state, as seen even today, were basically established at this time, with later periods seeing but minor expansions.

Economic achievements were startling. The era saw a huge volume of inter-state commerce. The merchant class achieved a high social status never to be repeated in later history; many merchants became statesmen, a move almost unimaginable in many of the later Chinese empires. ${ }^{92}$ Urbanization advanced to a very high degree: a dozen cities had populations in the hundreds of thousands. There was mercantilist thinking and economic inquiry. The most famous of these merchant-statesmen was Lu Bu Wei (ca 290-235 BC), a merchant who entered politics to become the Prime Minister in the Kingdom of Oin. ${ }^{93}$

\section{Conclusions}

In sum, the broad situation across Eurasia during the early classical era fits in well with the main argument of this book that major changes in military technology caused structural changes in international politics and, such technological and structural changes have great impact on the relativist concern, power-induced risk attitude and economic performance of the constituent states. Specifically, the history of the early classical world agrees with the main argument that a pluralistic international order encourages creativity and development and a monolithic international order results in conservatism and stagnation. During the early classical era, the pluralistic and competitive international political systems of Greece, India and China propelled their civilizations ahead and created splendid classical achievements while the monolithic international

92 Refer to Wesson (1978, pp. 44-45).

93 For the historicity of Guan Zi, refer to Fung (1966) and Bodde and Fung (1983). 
political systems of Greater Near East and western Mediterranean region stagnated. Building upon the achievements of the Near Eastern civilizations and propelled forward by the political military competition generated by the Greek city state system and Hellenistic state system, classical Greece was the most advanced of this era. Consequently, the ancient Near Eastern leadership in civilization ended. 